\title{
Analysis of Temperate Fruits Production in Himachal Pradesh: A comparative study of different blocks of district Shimla
}

\author{
Sikander Kumar ${ }^{1}$ and Vishal Chauhan ${ }^{2 *}$
}

${ }^{1}$ Professor \& Vice-Chancellor, Department of Economics, Himachal Pradesh University, Summer Hill, Shimla, Himachal Pradesh, India

${ }^{2}$ Former Research Scholar, Department of Economics, Himachal Pradesh University, Summer Hill, Shimla, Himachal Pradesh, India "Corresponding author: vishal.chauhan333.vc@gmail.com (ORCID ID: 0000-0001-8837-6122)

Received: $25-01-2021$

Revised: 04-03-2021

Accepted: 06-03-2021

\begin{abstract}
Being a principal factor of production land occupies an important position in agriculture production and plays a key role in determining resource efficiency therefore, $t$ he study was conducted to understand temperate fruits productivity of the different blocks of district Shimla in order to reveal the resource efficiency picture of different blocks. For studying resource efficiency, one has taken land as the main and principal resource and data of 10 years (2008-2018) for 10 Blocks being collected and analyzed with the help of regression and percentage method. It was found that in Almonds, Apricot, Cheery and Pears production at blocks Rampure and Jubbal \& Kotkhai are showing the highest average and per hectare productivity however the coefficient value of land concerned blocks Narkand,Rohru, Mashobra, and Jubbal \& Kotkhai is showing the highest land productivity for Almonds, Apricot, Cherry and Pears production, therefore, reveals the production and efficiency status of difference blocks of Shimla District.

\section{Highlights}

( Average, CAGR and land elasticity of Rampur and Narkanda Blocks is highest among all the given Blocks in Almonds production.

( Average productivity and Average per hectare productivity of Jubbal and Kotkhai, and Nankhari block is highest among all the other Blocks in cheery production.

( Mashobra and Jubbal \& Kotkhai are among the top two Blocks in Average and Average Per hectare production in Apricot production

( Block Jubbal and Kotkhai looks strong in Pears production.
\end{abstract}

Keywords: Average production, elasticity coefficient, land productivity, resource efficiency

Agro-climatic conditions of Himachal Pradesh has a wide range therefore many horticulture commodities like fruit crops (from temperate to subtropical), flowers, vegetables, mushrooms, hops, tea, medicinal \& aromatic plants, etc. are successfully grown here. The area under fruits, which was 792 hectares in 1950-51 with total production of 1,200 tonnes increased to $2,30,852$ hectares during 201718. The total fruit production in 2018-19 was 451822 (M.T) of which Apple constitutes 368603 (M.T), Other Temperate Fruits 37146 (M.T), Citrus Fruits 29344 (M.T), Nuts \& Dry Fruits 3649 (M.T) and
Other Sub-Tropical Fruits 13080 (M.T) (Department of Horticulture, Himachal Pradesh).

Several studies were conducted by Sharma Vashist. (1974), Bharadwaj (1980), Randev et al. (1992), Kulkarni (1994), Kumar et al. (2011), (Kireeti, 2013), Singh (2013), Chand et al. (2017), Singh et al. (2018), Ali et al. (2019), Jammalamadaka et al.

How to cite this article: Kumar, S. and Chauhan, V. (2021). Analysis of Temperate Fruits Production in Himachal Pradesh: A comparative study of different blocks of district Shimla. Economic Affairs, 66(1): 53-59.

Source of Support: None; Conflict of Interest: None (1) 8 
(2020) and Singh et al. (2020) regarding the InputOutput relation in the agriculture production and was revealed that Inputs like FYM, chemical fertilizers, human labour, has positive impact on the productivity hence showing a positive relationship between given inputs and output. However, land is one of the main factors of production in agriculture and had its major impact on farm production therefore the objective of the present study was to understand the efficiency and productivity of different Blocks of District Shimla for Different temperate fruit crops (Pears, Cheery, Almonds, Apricot)which will reveal the Resource efficiency picture of different Blocks with its resource endowment and extent of their use on farms, which is of a great importance for farmers and government to make practical recommendations for planning aimed at the better allocation of existing resources.

\section{MATERIALS AND METHODS}

The present study is based upon the time series secondary data collected from the published source of government Agencies. The data has been gathered from the Department of Horticulture, Govt of Himachal Pradesh. The study covers a period of 10 years from 2008 to 2018. The data of land (hectares) as independent variable and production (M.T.) dependent variable was collected for different crops of different blocks of district Shimla.

\section{Analytical Tools}

To analyze the results a simple tabular analysis was use. The collected data was analyzed with the help of Average and CAGR methods.

\section{(i) Average}

It is the method which had been used to calculate the Average production and Average area under production of different fruits for different blocks in order to do the comparative analysis,

$$
A=\frac{1}{n} \sum_{i=1}^{n} X_{i}
$$

$$
\begin{aligned}
& A=\text { Average } \\
& n=\text { number of values } \\
& X_{i}=\text { data set values }
\end{aligned}
$$

\section{(ii) Compound Annual Growth Rate}

It explains the Compound growth rate of area under production and production of different crops for different blocks for the given time period,

$$
C A G R=\left(V_{\text {final }} / V_{\text {begin }}\right)^{1 / t}-1
$$

$C A G R=$ compound annual growth rate

$V_{\text {begin }}=$ Beginning value

$V_{\text {final }}=$ Final value

$t=$ Time in years

However average, CAGR is a simple method that cannot explain the relationship between two variables therefore linear regression method has been used to found the relation between Land and Productivity.

(iii) Linear Regression

$$
Y=\beta_{0}+\beta_{1} X
$$

$Y=$ Gross Value of output of Respective Crop (M.T)

$\beta_{0}=$ Constant

$\beta_{1}=$ Elasticity Coefficient

$X=$ Size of the Operational Holding (Hectares)

\section{RESULTS AND DISCUSSION}

\section{Productivity and Resource Efficiency in Almonds Production}

Almonds are one of the important temperate crops and from Table 1 one will try to understand the resource efficiency picture of different Blocks in Almonds production. The Table reveals that the Average production and Average per hectare productivity of Rampur Block is highest with 117.7 (M.T) \& 1.028 (M.T) however Average area under Almonds crop production is concern it is highest with 369.052 (Hectares) of Block Theog. As far as CAGR of Almonds production (M.T) and Per hectare productivity (M.T) is concern Block Chiragon with $-3.82 \&-3.33$ percent is revealing maximum growth rate picture whereas Block Narkanda is reveling minimum CAGR picture for Almonds production (M.T) and Per hectare productivity (M.T) with -49.09 and -49.03 percent 
Table 1: Comparative Analysis of Different Blocks of District Shimla in Almonds Production for the period 2008-09 to 2017-18

\begin{tabular}{|c|c|c|c|c|c|c|c|c|c|}
\hline $\begin{array}{l}\text { Sl. } \\
\text { No. }\end{array}$ & BLOCKS & $\begin{array}{l}\text { Average } \\
\text { Area under } \\
\text { Almonds } \\
\text { Production } \\
\text { (hectares) }\end{array}$ & $\begin{array}{l}\text { Average } \\
\text { Almonds } \\
\text { Production } \\
\text { (MT) }\end{array}$ & $\begin{array}{l}\text { Average } \\
\text { Almonds } \\
\text { Per Hectare } \\
\text { Productivity } \\
\text { (MT) }\end{array}$ & $\begin{array}{l}\text { CAGR of } \\
\text { Area under } \\
\text { Almonds } \\
\text { Production } \\
\text { (Hectares) }\end{array}$ & $\begin{array}{l}\text { CAGR of } \\
\text { Almonds } \\
\text { Production } \\
\text { (MT) }\end{array}$ & $\begin{array}{l}\text { CAGR of } \\
\text { Almonds } \\
\text { Per Hectare } \\
\text { Productivity } \\
\text { (MT) }\end{array}$ & $\begin{array}{l}\text { Elasticity } \\
\text { Coefficient } \\
\text { of Land }\end{array}$ & R2 \\
\hline 1 & Mashobra & 158.55 & 72 & 0.453 & $-0.36 \%$ & $-15.16 \%$ & $-14.71 \%$ & 2.129 & $1.80 \%$ \\
\hline 2 & Basantpure & 98.728 & 14.67 & 0.145 & $-0.43 \%$ & $-12.24 \%$ & $-11.71 \%$ & 1.7051 & $26.49 \%$ \\
\hline 3 & Jubbal \& Kotkhai & 204.282 & 27.926 & 0.134 & $0.34 \%$ & $-8.62 \%$ & $-8.81 \%$ & -1.1006 & $11.96 \%$ \\
\hline 4 & Chiragon & 130.58 & 45.1 & 0.341 & $-0.22 \%$ & $-3.82 \%$ & $-3.33 \%$ & 3.381 & $25.38 \%$ \\
\hline 5 & Theog & 369.052 & 30.93 & 0.080 & $-0.16 \%$ & $-42.90 \%$ & $-42.55 \%$ & 8.2703 & $56.08 \%$ \\
\hline 6 & Nankhari & 76.273 & 72 & 0.946 & $-0.13 \%$ & $-27.90 \%$ & $-27.78 \%$ & 17.64 & $0.89 \%$ \\
\hline 7 & Rohru & 84.56 & 48.14 & 0.564 & $-0.21 \%$ & $-22.86 \%$ & $-22.62 \%$ & 30.137 & $40.90 \%$ \\
\hline 8 & Chopal & 111.88 & 22.52 & 0.197 & $-0.24 \%$ & $-42.11 \%$ & $-41.93 \%$ & 17.183 & $53.37 \%$ \\
\hline 9 & Narkanda & 147.37 & 115 & 0.77 & $-0.10 \%$ & $-49.09 \%$ & $-49.03 \%$ & 98.995 & $30.70 \%$ \\
\hline 10 & Rampur & 113.34 & 117.7 & 1.028 & $-0.34 \%$ & $-14.91 \%$ & $-14.58 \%$ & 36.79 & $47.86 \%$ \\
\hline
\end{tabular}

M.T-Metric Tonn; CAGR-Compound Annual Growth Rate.

growth rate. However, Block Basantpure with 14.67 (M.T.) is having minimum Average production and Block Theog with 0.08 (M.T.) has minimum Average per hectare productivity among all the Blocks.

When one look towards the resource efficiency it came to our picture that Block Narkanda is revealing maximum resource efficiency with a Land elasticity coefficient of 98.99, therefore, explaining that with every increase in the land by 1-hectare output is increasing by 98.99 (M.T) which is highest among all the other blocks whereas low land performance is concern it was revealed from the study that Jubbal \& Kotkhai Block with 1.1006 Elasticity coefficient of land is least among all the other Blocks hence revealing resource inefficiency picture of the Block. As far as the coefficient of determination (R2) is concernit reveals the percentage of variation in the dependent variable explained by the independent variable which is 30.70 percent for Block Narkanda and 11.96 percent for Block Jubbal \& Kotkhai.

Therefore, from the study, it is evident that Theog and J\&K Blocks is having more Average area under Almonds production but when it comes to Average Almond's productivity, they are among the last four Blocks of district Shimla however, on the other hand, Rampur and Narkanda Blocks are those who's Average, CAGR and land elasticity is highest among all the given Blocks.

\section{Productivity and Resource Efficiency in Apricot Production}

Apricot productivity of different Blocks can be observed from the given Table 2 and it was revealed from the Table that the Average and Average per hectare productivity of the Jubbal \& Kotkhai for given ten years is 66.77 (MT) and 1.05 (M.T) which is the highest among all the Blocks whereas Block Nankhari with 1.59 (M.T) \& 0.032 (M.T) production is lowest among all the other Blocks. However, when one looks towards CAGR for Apricot production (M.T) and Per hectare production (M.T) Block Rampure is leading with 9.33 and 9.22 percent growth rate whereas Block Nankhari is revealing minimum growth rate picture among all the other Blocks. As far as CAGR for Area under Apricot production is concern it is highest for Basantpure Block with 1.30 Percent and Lowest for Block Rohru with -0.19 percent.

When one look at it statically it was revealed from Table 2 that the Elasticity coefficient of land for Block Rohru is highest with 18.32 which specifies that with a 1.00 percent increase in land output will increasing by 18.32 percent however lowest land productivity is a concern Block Chopal with -3.5432 Elasticity coefficient is revealing resource inefficiency picture of Block in Apricot Production. However, the Coefficient of Determination (R2) is concern which is 54.31 percent for Block Rohru and 40.85 percent for Block Chopal, therefore, it explains 
Table 2: Comparative Analysis of Different blocks of District Shimla in Apricot production for the period 2008-09 to 2017-18

\begin{tabular}{|c|c|c|c|c|c|c|c|c|c|}
\hline $\begin{array}{l}\text { Sl. } \\
\text { No. }\end{array}$ & BLOCKS & $\begin{array}{l}\text { Average } \\
\text { Area under } \\
\text { Apricot } \\
\text { Production } \\
\text { (Hectares) }\end{array}$ & $\begin{array}{l}\text { Average } \\
\text { Apricot } \\
\text { Production } \\
\text { (MT) }\end{array}$ & $\begin{array}{l}\text { Average } \\
\text { Apricot Per } \\
\text { Hectare } \\
\text { Productivity } \\
\text { (MT) }\end{array}$ & $\begin{array}{l}\text { CAGR of } \\
\text { Area under } \\
\text { Apricot } \\
\text { Production } \\
\text { (Hectares) }\end{array}$ & $\begin{array}{l}\text { CAGR of } \\
\text { Apricot } \\
\text { Production } \\
\text { (MT) }\end{array}$ & $\begin{array}{l}\text { CAGR of } \\
\text { Apricot Per } \\
\text { Hectare } \\
\text { Productivity } \\
\text { (MT) }\end{array}$ & $\begin{array}{l}\text { Elasticity } \\
\text { Coefficient } \\
\text { of Land }\end{array}$ & R2 \\
\hline 1 & Mashobra & 101.09 & 41.19 & 0.405 & $0.93 \%$ & $-5.93 \%$ & $-6.68 \%$ & -1.6098 & $3.16 \%$ \\
\hline 2 & Basantpure & 61.791 & 4.6 & 0.071 & $1.30 \%$ & $6.75 \%$ & $5.51 \%$ & 0.4962 & $32.55 \%$ \\
\hline 3 & $\begin{array}{l}\text { Jubbal \& } \\
\text { Kotkhai }\end{array}$ & 63.09 & 66.77 & 1.05 & $0.72 \%$ & $-9.76 \%$ & $-10.33 \%$ & 1.2277 & $0.71 \%$ \\
\hline 4 & Chiragon & 41.06 & 8.55 & 0.206 & $0.59 \%$ & $-15.85 \%$ & $-16.20 \%$ & -0.3116 & $0.50 \%$ \\
\hline 5 & Theog & 89.04 & 8.18 & 0.088 & $-0.06 \%$ & $-22.57 \%$ & $-22.07 \%$ & 4.8707 & $19.61 \%$ \\
\hline 6 & Nankhari & 49.14 & 1.59 & 0.032 & $-0.12 \%$ & $-100.00 \%$ & $-100.00 \%$ & 4.6954 & $29.38 \%$ \\
\hline 7 & Rohru & 92.96 & 37.40 & 0.398 & $-0.19 \%$ & $-17.66 \%$ & $-17.48 \%$ & 18.32 & $54.31 \%$ \\
\hline 8 & Chopal & 56.15 & 9.67 & 0.171 & $0.55 \%$ & $-25.41 \%$ & $-25.60 \%$ & -3.5432 & $40.85 \%$ \\
\hline 9 & Narkanda & 76.16 & 21.62 & 0.281 & $0.88 \%$ & $-23.13 \%$ & $-23.71 \%$ & -0.527 & $0.34 \%$ \\
\hline 10 & Rampur & 74.79 & 27.48 & 0.365 & $0.17 \%$ & $9.33 \%$ & $9.22 \%$ & 8.2933 & $4.83 \%$ \\
\hline
\end{tabular}

M.T-Metric Tonn; CAGR-Compound Annual Growth Rate.

the variation in the Dependent variable explained by Independent Variable.

Therefore, from the study, it is evident that Block Mashobra \& Jubbal \& Kotkhai are among the top two Blocks in Apricots Average and Average Per hectare production however marginal productivity of land is concern Block Rohrus performance looks good hence reveals resource efficiency picture of the Block.

\section{Productivity and Resource Efficiency in Cherry Production}

Cherry is one of the temperate crops which has shown growth in Area under crop production and productivity in the past few years therefore from Table 3 one will understand the cherry productivity of different Blocks and it can be observed from the Table that the Average production of Jubbal \& Kotkhai block is highest with 295.38 (M.T) where as Average per hectare cherry productivity of Nankhari Block is highest with 4.858 (M.T) among all the other blocks. However, when one looks towards the CAGR of Cheery Production (M.T) and Cherry Per Hectare Production (M.T) it was found that Block Chiragon and Rohru hold the top position with a $25.99 \& 21.10$ percent growth rate. As far as Blocks with low performance is concern it was revealed from the study that in Average Cherry production (M.T) and Per Hectare Production (M.T)
Block Basantpure is lowest with 0.10 (M.T) and 0.121 (M.T) however Block Theog is least among all the other Blocks in CAGR of Cherry production (M.T) and Cherry Per Hectare Production (M.T). The study also reveals that Block chiragon is showing the highest CAGR in the Area under cherry production whereas Block Basantpure is showing Lowest CAGR in Area under cherry production.

As far as resource efficiency is concern with coefficient value of 4.0876 and 1.4719 Block Basantpur and Jubbal \& Kotkhai is revealing a positive picture hence specifies that marginal product of the land of given Blocks will increase by 4.08 (M.T) and 1.47 (M.T) with every increase in 1-hectare landwhich is first and second highest as compare to other Blocks however Nankhari and Rohru with coefficient value of -20.988 and -7.4274 are revealing lowest marginal productivity picture of land hence explaining resource inefficiency picture of Blocks. When one looks towards the Coefficient of Determination (R2) which explains variation in the dependent variable explained by the Independent variable and it was found to be 9.79 percent for Block Basantpure, 0,65 percent for Block Jubbal \& Kotkhai, 0.91 Percent for Block Nankhari and 56.45 percent for Block Rohru.

Therefore, the study reveals that the Narkanda block has the Highest area under cherry production but the Average productivity and Average per hectare productivity of Jubbal and Kot Khai and Nankhari 
Table 3: Comparative Analysis of Different Blocks of District Shimla in Cherry Production for the period 2008-09 to $2017-18$

\begin{tabular}{|c|c|c|c|c|c|c|c|c|c|}
\hline $\begin{array}{l}\text { S1. } \\
\text { No. }\end{array}$ & BLOCKS & $\begin{array}{l}\text { Average } \\
\text { Area under } \\
\text { Cheery } \\
\text { Production } \\
\text { (Hectares) }\end{array}$ & $\begin{array}{l}\text { Average } \\
\text { Cherry } \\
\text { Production } \\
\text { (MT) }\end{array}$ & $\begin{array}{l}\text { Average } \\
\text { Cheery Per } \\
\text { Hectare } \\
\text { Productivity } \\
\text { (MT) }\end{array}$ & $\begin{array}{l}\text { CAGR of } \\
\text { Area under } \\
\text { Cheery } \\
\text { Production } \\
\text { (Hectares) }\end{array}$ & $\begin{array}{l}\text { CAGR of } \\
\text { Cheery } \\
\text { Production } \\
\text { (MT) }\end{array}$ & $\begin{array}{l}\text { CAGR of } \\
\text { Cheery Per } \\
\text { Hectare } \\
\text { Productivity } \\
\text { (MT) }\end{array}$ & $\begin{array}{l}\text { Elasticity } \\
\text { Coefficient } \\
\text { of Land }\end{array}$ & R2 \\
\hline 1 & Mashobra & 13.35 & 13.31 & 0.973 & $-0.48 \%$ & $-4.79 \%$ & $-4.27 \%$ & 4.0876 & $56.30 \%$ \\
\hline 2 & Basantpure & 1.28 & 0.10 & 0.121 & $-11.96 \%$ & $-1.05 \%$ & $2.16 \%$ & -0.1016 & $9.79 \%$ \\
\hline 3 & $\begin{array}{l}\text { Jubbal \& } \\
\text { Kotkhai }\end{array}$ & 70.56 & 295.38 & 4.254 & $5.49 \%$ & $-10.99 \%$ & $-15.61 \%$ & 1.4719 & $0.65 \%$ \\
\hline 4 & Chiragon & 16.54 & 4.63 & 0.294 & $23.33 \%$ & $25.99 \%$ & $2.17 \%$ & 0.1493 & $3.94 \%$ \\
\hline 5 & Theog & 37.03 & 4.95 & 0.130 & $2.93 \%$ & $-100.00 \%$ & $-100.00 \%$ & 0.3714 & $6.01 \%$ \\
\hline 6 & Nankhari & 11.31 & 54.13 & 4.858 & $1.28 \%$ & $12.37 \%$ & $11.10 \%$ & -20.988 & $0.91 \%$ \\
\hline 7 & Rohru & 13.7 & 10.88 & 0.806 & $-0.96 \%$ & $19.58 \%$ & $21.10 \%$ & -7.4274 & $56.45 \%$ \\
\hline 8 & Chopal & 4.91 & 4.83 & 1.008 & $-4.49 \%$ & $0.00 \%$ & $5.23 \%$ & 0.5058 & $1.55 \%$ \\
\hline 9 & Narkanda & 164.30 & 140.38 & 0.851 & $1.10 \%$ & $-0.31 \%$ & $-1.27 \%$ & 0.7193 & $0.53 \%$ \\
\hline 10 & Rampur & 16.25 & 2.92 & 0.185 & $1.35 \%$ & $-14.74 \%$ & $-15.76 \%$ & -1.9951 & $30.36 \%$ \\
\hline
\end{tabular}

M.T-Metric Tonn; CAGR-Compound Annual Growth Rate.

Table 4: Comparative Analysis of Different blocks of District Shimla in Pears Production for the period 2008-09 to 2017-18

\begin{tabular}{|c|c|c|c|c|c|c|c|c|c|}
\hline $\begin{array}{l}\text { Sl. } \\
\text { No. }\end{array}$ & BLOCKS & $\begin{array}{l}\text { Average } \\
\text { Area under } \\
\text { Pears } \\
\text { Production } \\
\text { (Hectares) }\end{array}$ & $\begin{array}{l}\text { Average } \\
\text { Pears } \\
\text { Production } \\
\text { (MT) }\end{array}$ & $\begin{array}{l}\text { Average } \\
\text { Pears Per } \\
\text { Hectare } \\
\text { Productivity } \\
\text { (MT) }\end{array}$ & $\begin{array}{l}\text { CAGR of } \\
\text { Area under } \\
\text { Pears } \\
\text { Production } \\
\text { (Hectares) }\end{array}$ & $\begin{array}{l}\text { CAGR } \\
\text { of Pears } \\
\text { Production } \\
\text { (MT) }\end{array}$ & $\begin{array}{l}\text { CAGR of } \\
\text { Pears Per } \\
\text { Hectare } \\
\text { Productivity } \\
\text { (MT) }\end{array}$ & $\begin{array}{l}\text { Elasticity } \\
\text { Coefficient } \\
\text { of Land }\end{array}$ & R2 \\
\hline 1 & Mashobra & 264.58 & 200.26 & 0.756 & $0.25 \%$ & $-3.67 \%$ & $-3.88 \%$ & -14.722 & $10.81 \%$ \\
\hline 2 & Basantpure & 113.67 & 38.87 & 0.338 & $0.45 \%$ & $5.84 \%$ & $5.62 \%$ & -0.949 & $0.60 \%$ \\
\hline 3 & Jubbal \& Kotkhai & 488.85 & 3830.75 & 7.815 & $0.57 \%$ & $12.67 \%$ & $12.12 \%$ & 77.382 & $9.33 \%$ \\
\hline 4 & Chiragon & 95.47 & 44.70 & 0.470 & $3.43 \%$ & $-11.71 \%$ & $-14.61 \%$ & -0.0466 & $0.02 \%$ \\
\hline 5 & Theog & 229.9 & 190.52 & 0.827 & $0.45 \%$ & $-37.56 \%$ & $-37.81 \%$ & -2.8424 & $0.44 \%$ \\
\hline 6 & Nankhari & 32.89 & 28.88 & 0.895 & $-0.77 \%$ & $31.45 \%$ & $32.79 \%$ & -17.756 & $44.59 \%$ \\
\hline 7 & Rohru & 117.50 & 47.85 & 0.404 & $2.31 \%$ & $3.28 \%$ & $1.13 \%$ & 0.487 & $3.86 \%$ \\
\hline 8 & Chopal & 112.51 & 742.7 & 6.694 & $0.95 \%$ & $-26.88 \%$ & $-27.56 \%$ & -98.622 & $43.48 \%$ \\
\hline 9 & Narkanda & 104.11 & 84.66 & 0.811 & $0.26 \%$ & $-17.99 \%$ & $-18.20 \%$ & 2.2081 & $0.39 \%$ \\
\hline 10 & Rampur & 52.65 & 6.19 & 0.116 & $0.38 \%$ & $-17.68 \%$ & $-17.79 \%$ & -2.1178 & 0.0403 \\
\hline
\end{tabular}

M.T-Metric Tonn; CAGR-Compound Annual Growth Rate.

block is the highest whereas the land productivity of Mashobra block is highest among all the Blocks.

\section{Productivity and Resource Efficiency in Pears Production}

Pears is the second most productive temperate crop of area and from Table 4 one can reveal the Pears productivity of different blocks of district Shimla and therefore one can observe that the Average Pear productivity and Average per hectare productivity for 10 years of Jubbal \& Kotkhai block is highest with 3830.75 (M.T) and 7.815 (M.T) and lowest for
Block Rampure with 6.19 (M.T) and 0.116 (M.T) among all the other Blocks. As far as CAGR is concerned Block Nankhari leads all the other Blocks with 31.45 and 32.79 percent growth rate whereas on the other hand Block Theog with -37.56 and -37.81 percent has the least growth rate for Pears production (M.T) and Per hectare production (M.T). However, Block Chiragon is showing the highest growth rate in Area under production with 3.43 percent.

When one look towards the land productivity, it has been revealed from the table that Jubbal \& 
Kotkhai Block is highest among all the Blocks with a coefficient value of 77.382, therefore, specifies that the production of Pears will increase by 77.32 (M.T) with every increase of land by 1.00 (Hectare) whereas with coefficient value of -98.622 Block Chopal is lowest among all the other blocks. As far as the Coefficient of Determination (R2) is concern it is 9.33 percent for Jubbal and Kotkhai Block and 43.48 percent for Block Chopal, therefore, it reveals the percentage explanation of variation in the dependent variable (M.T) due to independent Variable (Land).

Therefore, from the study, it is evident that Jubbal and Kotkhai Block is efficient in the Pears production whether it is Average production or Marginal productivity of land hence revelling the resource efficiency picture of the Block among other blocks.

\section{CONCLUSION}

Thus, from the research one can conclude that there is no necessary relationship between Area under crop production and Average, CAGR, and Marginal productivity of the land. It has been observed that in Almonds production Theog and J\&K Blocks is having more Average area under Almonds production but in case of output Rampur and Narkanda Blocks Average, CAGR and land elasticity is highest among all the given Blocks, similarly in cherry production Narkanda block has Highest area under cherry production but Average productivity and Average per hectare productivity of Jubbal and Kotkhai and Nankhari block is highest whereas in land productivity Mashobra Block is highest among all the Blocks. It has also been found that in Apricot production Block Mashobra \& Jubbal \& Kotkhai are among the top two Blocks in Average and Average Per hectare production but in the case of marginal productivity of land Block Rohru, performance looks good. As far as in Pears production Block Jubbal and Kotkhai looks strong as it not only occupies more land under crop production but also having the highest Average production with efficient land productivity.

Therefore, the study reveals the performance of different Blocks of district Shimla in different crop production which explains inconsistency among different Blocks regarding production and resource efficiency hence becomes a base for farmers to plan and manage the resource properly with improving farm technology, farm knowledge, advance farming methodology, etc. Also, the study is important from the government point of view to identify the constraints and gaps which needed to be filled with proper government policies/programs (Subsidies, Benefits, Agri Infrastructure, Lab Facilities).

\section{REFERENCES}

Ali, J., Kachroo, J., Bhat, D.J., Rizvi, S.E.H., Sharma, B.C. and Dwivedi, S. 2019. Analysis of Resource use Efficiency in Apple Production on Outer Himalayan Range of Chenab Valley. Econ. Affa., 64(1): 69-76.

Bharadwaj, A.N., Swarup, R. and Nadda, A.L. 1980. ResourceUse Efficiency in Wheat and Maize: A Comparative Study of HYV's and Local Varieties in District Bilaspur of Himachal Pradesh. Agro Economics Research Center, Himachal Pradesh University, Shimla.

Bhat, G.M. and Dhar, M.K. 1989. Resource Use Efficiency of Apple Cultivation in Jammu and Kashmir State, Ind. J. Econ., 4(3): 611-616.

Chand, H., Guleria, C., Guleria, A. and Kashyap, R. 2017. Resource use efficiency and marketing analysis of apple crop in Shimla district of Himachal Pradesh. Int. J. Farm Scien., 7(1): 1-6.

Government of Himachal Pradesh. "Overview of Himachal Pradesh", Department of Horticulture, Himachal Pradesh, Shimla.

Government of Himachal Pradesh, "Himachal Pradesh Economic Survey", Directorate of Economics \& Statistics, Himachal Pradesh, 2018-2019.

Jammalamadaka, A. and Deka, N. 2020. Factors Affecting Production of Flood Tolerant Rice Variety in Assam: A Farm Level Study. Econ. Affa., 65(3): 445-449.

Kireeti, K. 2013. Productivity Analysis of Apple Orchards in Shimla District of Himachal Pradesh. M.Sc. Thesis, Dr YSPUHF, Nauni, Solan, Himachal Pradesh, (India).

Kumar, V., Sharma, R.K. and Sharma, K.D. 2011. Resourceuse Efficiency in Agriculture in Himachal Pradesh. Agril. Situation in India, 68(2): 75-81.

Kulkarni, B.S., Choudry, K.R. and Krishna, R.G.V. 1994. Resource Productivity, Returns to Scale and Resource Use Efficiency in Paddy Farm of Rangareddy District of Andhra Pradesh. Agril. Situation in India, 49(9): 643-647.

Masoodi, M.A. 2003. Agriculture in Jammu and Kashmir-A Perspective. Mohisraw Book Series, Srinagar, pp. 195.

Randev, A.K., Tewari, S.C. and Sharma, R.K. 1992. Rationale of Resource use in Apple Cultivation - A case Study of Tribal area in Himachal Pradesh. Ind. J. Agril. Econ., 47(4): 669-676.

Singh, I.J. 2013. Impact of Climate Change on the Apple Economy of Himachal Pradesh: A Case Study of Kotgarh Village. In Ecology \& Tourism, LVIV: 20-25. 
Analysis of Temperate Fruits Production in Himachal Pradesh...

Singh, P., Vaidya, M.K. and Gulari, A. 2018. Economic Efficiency of Input Use in Peach Cultivation in NorthWestern Himalayas. Eco. Affa., 63(3): 605-610.

Singh, A., Kumar, D.B., Kumar, N. and Kumar, R. 2020. Resource Use Efficiency in Wheat under different Techniques in Haryana. Indian J. Econ. Dev., 7(ss): 260-266.
Tewari, S.C., Sharma, R.K. and Vashist, G.D. 1974.Consumption of Pesticides in Kulu Orchards. East Econ., 13(1,9): 841-3. 
